church and school registers, diaries, photographs, etc. Dr. Humphrey Fisher, visiting Fourah Bay College from S.O.A.S., was responsible for the Arabic section of this exhibition for which some very valuable material was gathered. A good deal of the unpublished material was donated during the exhibition by visitors who realized that they too had something worthy of display. The unpublished manuscripts and rare printed materials are being microfilmed by the College Library for historical research. A number of manuscripts have been deposited with the Library or the National Archives.

A catalogue of these materials is being prepared in two parts by Messrs. Errol Magidson and H. M. Zell: part one on unpublished and out-of-print writings and part two on published writings in print and available. Inquiries and provisional orders should be sent to the Manager, Fourah Bay College Bookshop, Freetown, Sierra Leone. (Communicated by Mr. Michael Crowder, Director, Institute of African Studies,
Fourah Bay College)

\title{
Conference on Research in Dance
}

African dance was discussed at a recent conference on 'Research in Dance: Problems and Possibilities', sponsored by the Committee on Research in Dance and held from 26 to 28 May at Teachers College, Columbia University, New York City. Judith Lynne Hanna of the American University, Washington D.C., gave a paper on dance field research, in which she explored the contextual study of African dance and examined the practical utility of such research for the dance teacher, the choreographer, and the performer.

\section{Bibliography on Economic Development of Nigeria, 1950-1964}

Mrs. A. O. IKe, Serials Librarian of the University of Nigeria, Nsukka, the compiler of this bibliography, has informed us that about 140 copies are still available. Prices are: ros. 6d. (Nigeria), iss. (Europe), and $\$ 2.50$ (U.S. and Canada).

\section{African Studies at the University of Mainz}

Professor Eike HaberLand has been director of the Institute of Ethnology at the University of Mainz since March 1965 . He has taken part in two expeditions to Southern Ethiopia and lectures on the cultural anthropology and history of Africa. Other members of the Institute are Dr. Erika Sulzmann, who has made five field trips to the Congo, and is now working on the sociology and political institutions, history and sacred kingship of the peoples of northwestern Congo, and Dr. Klaus Müller, who is preparing a cultural-historical study of the influence of mediterranean cultures on Africa. The Institute's future studies will concentrate mainly on Africa and it will participate in work on ethnological problems connected with the Africa mapping project inaugurated by the Deutsche Forschungsgemeinschaft.

African studies at the University of Mainz are also being carried out by Professor Dr. Eugen Rapp (Institutum Judaicum) who is translating the Bible into Twi and has recently made two field research trips to North-Eastern Nigeria to study Chado-hamitic languages. Two dictionaries on the Glawda and Yaghwatadaxa languages are in preparation. 